\title{
Intoleransi Laktosa pada Anak dengan Nyeri Perut Berulang
}

\author{
Elizabeth Yohmi, * Aswitha D. Boediarso, ${ }^{* *}$ Badriul Hegar, ** Pramita G. Dwipurwantoro, ** \\ Agus Firmansyab**
}

\begin{abstract}
Sakit perut berulang (SPB) merupakan masalah yang sering ditemukan pada anak terutama dalam hal pendekatan diagnosis dan tatalaksana. Sebagian besar penyebab SPB adalah gangguan fungsional dan hanya sebagian kecil (10\%) yang disebabkan oleh kelainan organik. Intoleransi laktosa dilaporkan merupakan penyebab SPB terbanyak pada anak berusia di atas 5 tahun. Intoleransi laktosa terjadi akibat ketidakmampuan laktase menghidrolisis laktosa yang masuk ke dalam usus halus. Manifestasi klinis yang diperlihatkan sangat bervariasi seperti mual, muntah, sakit perut, kembung, sering flatus dan diare. Berbagai pemeriksaan penunjang dapat digunakan untuk mendiagnosis keadaan intoleransi laktosa. Uji hidrogen napas merupakan alat diagnostik pilihan saat ini, karena bersifat non invasif dan mempunyai nilai sensitifitas dan spesifisitas yang tinggi, serta sangat mudah dan aman dilakukan pada anak. Biopsi usus masih merupakan uji diagnostik baku emas untuk mengukur aktivitas laktase. Prevalens intoleransi laktosa di berbagai tempat di dunia sangat beragam. Ras dan pola hidup dalam mengkonsumsi susu/produk susu dilaporkan berperan pada aktivitas laktase. Di Indonesia, prevalens intoleransi laktosa pada anak pernah dilaporkan dengan memperlihatkan peningkatan prevalens sesuai dengan bertambahnya usia, tetapi prevalens intoleransi laktosa pada anak yang menderita SPB belum pernah dilaporkan.
\end{abstract}

Kata kunci: intoleransi laktosa - sakit perut berulang - uji hidrogen napas

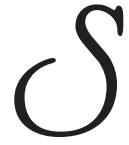

akit perut berulang merupakan masalah yang sering ditemukan pada anak terutama dalam hal pendekatan diagnosis dan tatalaksana. Pada sebagian anak, rasa nyeri dapat timbul setiap hari, sedangkan pada anak yang lain timbul secara episodik. ${ }^{1}$ Keluhan ini merupakan 5\% dari keseluruhan kasus

PPDS IKA FKUI-RSCM, Bagian Ilmu Kesehatan Anak, Jakarta ( Dr. Elizabeth Yohmi) dan Subbagian Gastroenterologi IKA FKUI-RSCM, Jakarta (Dr. Aswitha D. Boediarso Sp.A(K), Dr. Badriul Hegar Sp.A, Dr. Pramita G. Dwipurwantoro Sp.A dan Prof. DR. Dr. Agus Firmansyah Sp.A(K)).

Alamat korespondensi:

Dr. Elizabeth Yohmi

PPDS IKA FKUI-RSCM, Bagian Ilmu Kesehatan Anak Jl. Salemba No. 6 Jakarta 10430.

Tel 021- 314 8610, Fax. 021-. 3913982. yang datang ke dokter spesialis anak. Sebagian besar kasus mempunyai masalah dalam pendekatan diagnosis dan tatalaksananya, sehingga seringkali membuat frustasi baik orangtua, dokter, maupun pasiennya sendiri ${ }^{2}$

Sebagian besar penyebab SPB adalah gangguan fungsional dan hanya sebagian kecil yang disebabkan oleh kelainan organik. Pada laporan terdahulu, hanya sedikit sekali penyebab organik yang diketahui, yaitu sebesar 5-10\%, sehingga faktor emosional dan psikogenik sering dianggap sebagai penyebab gejala ini. ${ }^{3}$ Ada beberapa peneliti yang menganggap bahwa SPB pada anak dipengaruhi oleh faktor makanan. ${ }^{3}$ Van der Meer, dkk (1992) menemukan intoleransi laktosa sebagai penyebab SPB terbanyak pada anak berusia di atas 5 tahun. ${ }^{4}$ Penelitian terbaru menunjukkan bahwa $30-40 \%$ anak dengan SPB mempunyai penyebab 
organik seperti irritable bowel syndrome, penyakit seliak, infeksi H.pylori, penyakit Crohn atau kolitis ulseratif, dan malabsorpsi laktosa. ${ }^{5}$

\section{Sakit Perut Berulang}

Sakit perut berulang adalah serangan sakit perut yang timbul sekurang-kurangnya tiga kali dalam jangka waktu tiga bulan dan mengakibatkan terganggunya aktivitas sehari-hari. ${ }^{6}$ Angka kejadian SPB pada anak diprakirakan sebesar 10-15\% pada usia 4-14 tahun, sedangkan frekuensi tertinggi ditemukan pada usia 510 tahun. ${ }^{7-12}$ Anak perempuan cenderung lebih sering menderita sakit ini dibanding anak lelaki (perempuan: lelaki $=5: 3) .5,12$

Beberapa petunjuk yang dapat digunakan untuk membantu melakukan pendekatan diagnosis. Adanya beberapa alarm symtoms pada seorang anak yang menderita SPB perlu dipikirkan kemungkinan adanya kelainan organik yang mendasari keluhan tersebut. ${ }^{13,14}$ (Tabel 1)

Adanya kelainan fungsional sebagai penyebab keluhan SPB pada anak perlu dipikirkan bila ditemukan gejala klinis di bawah ini (Tabel 2). ${ }^{14}$

\section{Intoleransi Laktosa}

Beberapa peneliti menunjukkan bahwa intoleransi laktosa memegang peranan pada timbulnya gejala

Tabel 1. Alarm symptoms sakit perut berulang yang merupakan petanda kelainan organik $^{14}$

- Nyeri terlokalisir, jauh dari garis tengah

- Nyeri menjalar (punggung, bahu, ekstremitas bawah)

- Membangunkan anak pada malam hari

- Timbul tiba-tiba

- Muntah

- Gangguan motilitas (diare, obstipasi, inkontinensia)

- Perdarahan saluran cerna

- Disuria

- Gangguan tumbuh kembang

- Gejala sistemik: panas, atralgia, ruam kulit

- Riwayat keluarga: ulkus peptikum, infeksi H.pylori, intoleransi laktosa, IBS

- Kesadaran menurun sesudah episode sakit

- Usia kurang dari 4 tahun dan lebih dari 15 tahun

*IBS : inflammatory bowl syndrome
SPB pada anak. ${ }^{3}$ Peran intoleransi laktosa pada kejadian SPB dihubungkan dengan adanya ketidakmampuan laktase untuk menghidrolisis laktosa secara optimal. Seperti kita ketahui bahwa laktosa merupakan sumber karbohidrat utama di dalam susu dan beberapa makanan bayi atau anak. Akibat dari ketidakmampuan tersebut timbulah berbagai gejala gastrointestinal. Istilah intoleransi laktosa digunakan sebagai suatu sindrom klinik yang ditandai dengan nyeri perut, kembung, flatulen, diare, muntah, atau kemerahan di sekitar anus setelah mengkonsumsi laktosa ${ }^{15-19}$ Aktivitas laktase yang rendah sering dijumpai pada anak berusia diatas 5 tahun yaitu 3\% anak usia 5-10 tahun di Eropa Utara, sedangkan di daerah Asia Timur mencapai 80\%. Keadaan ini dihubungkan dengan penurunan aktivitas laktase secara genetik. ${ }^{20}$

\section{Laktosa}

Laktosa diproduksi oleh kelenjar payudara dengan kadar yang bervariasi diantara mamalia. Susu sapi mengandung 4\% laktosa, sedangkan ASI mengandung 7\% laktosa. ${ }^{21-22}$ Laktosa adalah disakarida yang terdiri dari komponen glukosa dan galaktosa. Manusia normal tidak dapat menyerap laktosa, oleh karena itu laktosa harus dipecah dulu menjadi komponenkomponennya. Hidrolisis laktosa memerlukan enzim laktase yang terdapat di brush border sel epitel usus halus. Tidak terdapatnya atau berkurangnya aktivitas laktase akan menyebabkan terjadinya malabsorpsi laktosa. ${ }^{15}$

Tabel 2. Gejala klinis sakit perut berulang fungsional ${ }^{14}$

- Paroksismal

- Daerah periumbilikalis atau suprapubik

- Nyeri berlangsung kurang dari 1 jam

- Nyeri tak menjalar, kram atau tajam, tak membangunkan anak malam hari

- Nyeri tak berhubungan dengan makanan, aktivitas, kebiasaan buang air besar

- Mengganggu aktivitas

- Diantara 2 episode terdapat bebas gejala

- Pemeriksaan fisik normal, kecuali kadang-kadang nyeri perut di kiri bawah

- Nilai laboratorium normal 


\section{Defisiensi Laktase}

Defisiensi laktase dapat dibedakan menjadi dua kelompok, yaitu defisiensi laktase primer dan defisiensi laktase sekunder. ${ }^{15}$

Terdapat 3 bentuk defisiensi laktase primer, yaitu

1. Developmental lactase deficiency

Terdapat pada bayi prematur dengan usia kehamilan 26-32 minggu. Kelainan ini terjadi karena aktivitas laktase belum optimal. ${ }^{22}$

2. Congenital lactase deficiency

Kelainan dasarnya adalah tidak terdapatnya enzim laktase pada brush border epitel usus halus. Kelainan ini jarang ditemukan dan menetap seumur hidup ${ }^{22}$

3. Genetical lactase deficiency

Kelainan ini timbul secara perlahan-lahan sejak anak berusia 2-5 tahun hingga dewasa. Kelainan ini umumnya terjadi pada ras yang tidak mengkonsumsi susu secara rutin dan diturunkan secara autosomal resesif. ${ }^{15}$

Defisiensi laktase sekunder terjadi akibat adanya penyakit gastrointestinal yang menyebabkan kerusakan mukosa usus halus, seperti infeksi saluran cerna, malnutrisi dan lain-lainnya. Gangguan ini umumnya bersifat sementara dan aktivitas laktase akan normal kembali setelah penyakit dasarnya disembuhkan. ${ }^{13}$ Defisiensi laktase sekunder juga dapat disebabkan oleh obat-obatan tertentu seperti kanamisin, neomisin, dan metotreksat. ${ }^{15}$

\section{Patofisiologi}

Laktosa tidak dapat diabsorpsi sebagai disakarida, tetapi harus dihidrolisis dahulu menjadi glukosa dan galaktosa dengan bantuan enzim laktase di usus halus. ${ }^{15,18,19}$ Bila aktivitas laktase turun atau tidak ada, maka laktosa yang tidak diabsorpsi akan mencapai usus bagian distal atau kolon. ${ }^{23,24}$ Adanya laktosa di lumen usus mengakibatkan tekanan osmotik meningkat dan menarik air dan elektrolit sehingga akan memperbesar volume di dalam lumen usus. Keadaan ini akan merangsang peristaltik usus halus sehingga waktu singgah dipercepat dan mengganggu penyerapan. ${ }^{23}$

Di kolon, laktosa akan difermentasi oleh bakteri kolon dan menghasilkan asam laktat dan asam lemak rantai pendek lainnya seperti asam asetat, asam butirat dan asam propionat. ${ }^{24}$ Fenomena ini menerangkan feses yang cair, asam, berbusa ${ }^{15,16,23}$, dan kemerahan pada kulit di sekitar dubur (eritema natum). ${ }^{25}$ Fermentasi laktosa oleh bakteri di kolon juga menghasilkan beberapa gas seperti hidrogen, metan dan karbondioksida yang akan mengakibatkan distensi abdomen, nyeri perut, dan flatus. ${ }^{24}$

Feses yang dihasilkan sering mengapung karena kandungan gasnya yang tinggi dan juga berbau busuk. ${ }^{22}$ Selanjutnya, $80 \%$ dari gas tersebut akan dikeluarkan melalui rektum dan sisanya akan berdifusi ke dalam sistim portal dan dikeluarkan melalui sistim pernapasan. ${ }^{32,24}$

\section{Gejala Klinis}

Intoleransi laktosa dapat bersifat asimtomatis atau memperlihatkan berbagai gejala klinis. ${ }^{24}$ Berat atau ringan gejala klinis yang diperlihatkan tergantung dari aktivitas laktase di dalam usus halus, jumlah laktosa, cara mengkonsumsi laktosa, waktu pengosongan lambung, waktu singgah usus, flora kolon, dan sensitifitas kolon terhadap asidifikasi. ${ }^{15,20,22}$

Gejala klinis yang diperlihatkan dapat berupa rasa mual, muntah, sakit perut, kembung dan sering flatus. Rasa mual dan muntah merupakan salah satu gejala yang paling sering ditemukan pada anak. Pada uji toleransi laktosa rasa penuh di perut dan mual timbul dalam waktu 30 menit, sedangkan nyeri perut, flatus dan diare timbul dalam waktu 1-2 jam setelah mengkonsumsi larutan laktosa. ${ }^{20}$

\section{Pendekatan Diagnosis}

Cara termudah mendiagnosis intoleransi laktosa adalah dengan melakukan eliminasi diet yang mengandung laktosa. Gejala akan timbul kembali apabila diberikan kembali diet yang mengandung laktosa. ${ }^{5}$

Diagnosis intoleransi laktosa ditetapkan berdasarkan kombinasi dari penemuan klinis dan pemeriksaan penunjang. Beberapa pemeriksaan penunjang yang dapat digunakan untuk mendiagnosis intoleransi laktosa, yaitu :

\section{Analisis tinja}

Cara ini merupakan uji diagnostik yang paling sederhana dan dapat digunakan sebagai uji tapis. Prinsipnya adalah ditemukan asam dan bahan 
pereduksi dalam tinja setelah minum atau makan yang mengandung laktosa. ${ }^{15}$ Ada 3 macam metode yang digunakan, yaitu:

a. Metode Clinitest

Metode clinitest bersifat kualitatif karena ion $\mathrm{H}$ dan gula dipengaruhi oleh kandungan air dalam tinja. ${ }^{15}$ Prinsip kerja metode ini berdasarkan terjadinya reduksi ion cupri $\left(\mathrm{C}_{\mathrm{U}} \mathrm{SO}_{4}\right){ }^{23}$

b. Kromatografi tinja

Pemeriksaan ini menggunakan kertas kromatografi untuk mengidentifikasi adanya gula dalam tinja. ${ }^{15}$

c. $\mathrm{pH}$ tinja

Pada intoleransi laktosa, tinja bersifat asam dengan $\mathrm{pH}$ kurang dari 6 dimana terdapat bahan pereduksi lebih dari $0,5 \% .^{4,15}$

2. Uji toleransi laktosa

Uji ini bersifat kuantitatif. ${ }^{15}$ Pada uji ini pasien dipuasakan selama 4-8 jam dan kemudian diberi minum larutan laktosa sebanyak $2 \mathrm{~g} / \mathrm{kg}$ berat badan (maksimum 50g) dalam konsentrasi 20\%. Kadar gula darah diperiksa selama 2 jam dengan interval 30 menit. Kenaikan kadar gula darah kurang dari $20 \mathrm{mg} \%$ dari nilai basal dianggap abnormal. ${ }^{15,23,25,26}$

3. Pemeriksaan radiologis minum barium-laktosa Pemeriksaan radiologis dilakukan dengan memberi minum barium yang telah dicampur dengan larutan laktosa sebelumnya. Bila terdapat malabsorpsi laktosa, seri foto usus akan memperlihatkan dilusi barium dan dilatasi lumen usus. Pemeriksaan ini sudah jarang dilakukan, karena adanya paparan terhadap radiasi. ${ }^{15}$

4. Ekskresi galaktosa pada urin

Sebagian besar (88-94\%) galaktosa yang terbentuk dari hasil hidrolisis laktosa di dalam usus halus akan di bersihkan di dalam hati dan diekskresi melalui urin. Reabsorpsi galaktosa di tubulus ginjal jauh lebih sedikit dibanding glukosa, sehingga ekskresi galaktosa di urin hampir sempurna. Dengan memberikan minum larutan laktosa sebesar $2 \mathrm{~g} / \mathrm{kg}$ berat badan dapat diukur kadar galaktosa di dalam urin. Diagnosis malabsorpsi laktosa ditegakkan bila ditemukan kadar galaktosa di dalam urin sebesar $0,9 \mathrm{mmol} /$ $\mathrm{L}$ atau kurang. ${ }^{27}$

\section{Uji hidrogen napas}

Uji hidrogen napas merupakan metoda pilihan untuk menentukan malabsorpssi laktosa karena bersifat non invasif, tidak menyakitkan dan mempunyai sensitifitas (80\%) dan spesifisitas (100\%) yang tinggi. ${ }^{28}$ Dasar metoda ini adalah mengukur kadar gas hidrogen yang dikeluarkan melalu udara napas, sebagai hasil fermentasi laktosa oleh flora kolon. Makin banyak hidrogen yang terukur berarti makin banyak laktosa yang difermentasikan, berarti makin banyak laktosa yang tidak diabsorpsi di usus halus. ${ }^{15}$

Setelah dipuasakan selama 4-6 jam, pasien diberikan larutan laktosa sebanyak $2 \mathrm{~g} / \mathrm{kg}$ berat badan (maksimum 50g) dalam konsentrasi 20\% ${ }^{14}$ atau $10 \%$ untuk bayi usia kurang dari 6 bulan. ${ }^{29}$ Sampel udara napas diambil setiap 30 menit dari sejak puasa, selama 2 jam. Konsentrasi gas hidrogen dapat diukur dengan menggunakan gas kromatografi atau laktometer. Diagnosis malabsorpsi laktosa ditegakkan bila terdapat kenaikan kadar hidrogen sama atau lebih dari 20 ppm di banding nilai basal (saat puasa). ${ }^{15,29}$

\section{Biopsi usus dan pengukuran aktivitas laktase}

Metode ini merupakan baku emas pemeriksaan aktivitas laktase. Biopsi mukosa usus dapat dilakukan secara endoskopi atau peroral. Nilai normal untuk neonatus adalah $38 \pm 4 \mathrm{U} / \mathrm{g}$ protein dan $18 \pm 4 \mathrm{U} / g$ protein untuk usia di atas 5 tahun. ${ }^{15}$

\section{Prevalensi Intoleransi Laktosa}

Sejak tiga puluh lima tahun terakhir telah dilakukan penelitian mengenai prevalens intoleransi laktosa baik pada orang dewasa maupun pada anak di berbagai negara. Walaupun metoda yang digunakan berbeda, tetapi didapatkan gambaran distribusi geografi intoleransi laktosa yang dapat dipercaya. Satu hal yang sangat menarik adalah distribusi tersebut sesuai dengan distribusi budaya suatu populasi dalam hal memelihara hewan ternak dan mengkonsumsi susu atau produk susu hewan ternak tersebut. ${ }^{15}$

Prevalens intoleransi laktosa sangat bervariasi di seluruh dunia. Prevalensi tertinggi umumnya terdapat pada populasi yang secara kultural tidak mengkonsumsi susu atau produk susu setelah masa penyapihan, yaitu berkisar antara 67-100\% pada penduduk asli Amerika dan Australia, 95\% pada sebagian besar negara di 
Amerika Selatan (Columbia, Peru, Suriname), 90\% pada sebagian besar negara di Asia (Jepang, Thailand, Cina, Taiwan dan Indonesia) serta $85 \%$ pada kebanyakan negara di Afrika (Etiopia, Nigeria dan Afrika Selatan). ${ }^{15}$

Prevalens yang tinggi juga terjadi akibat sedikitnya perkawinan antara populasi pencerna laktosa dengan populasi bukan pencerna laktosa, seperti yang terjadi pada orang Indian dan kulit hitam dari Amerika Utara. Prevalens yang sangat bervariasi ditemukan pada orang Eskimo yang berkawin campur dengan orang kulit putih dari Eropa Utara. ${ }^{15}$

Prevalens intoleransi laktosa terendah, yaitu 0-17\% ditemukan pada populasi Kaukasian dari Eropa Utara, kelompok suku-suku tertentu di Afrika (Tutsi dari Rwannda, Hima dari Uganda, Fulani dari Nigeria, dan Peuhl dari Sinegal), serta dari India Utara dan India Barat. Mereka mengkonsumsi susu atau produk susu setelah masa penyapihan sampai dewasa. Pada populasi di daerah Timur Tengah dan Timur Dekat (Iran, Jordan, Syria dan Israel), India dan sekitar Mediterania (Greek, Italia), prevalens intoleransi laktosa membentuk zona transisi berkisar 30-100\%. ${ }^{20}$

Di Amerika Selatan, intoleransi laktosa dilaporkan mulai terlihat setelah anak berusia 1 tahun, sedangkan pada populasi Kaukasian setelah usia 5 tahun dan Finlandia setelah usia remaja. ${ }^{20}$ Di Indonesia, Sunoto dkk pada tahun 1971 melaporkan prevalens malabsorpsi laktosa pada anak berusia 1-6 tahun sebesar $72 \%$ dengan menggunakan metoda uji toleransi laktosa. ${ }^{30,31}$ Pada tahun 1997, Hegar dkk dengan metode uji hidrogen napas melaporkan kejadian malabsorpsi laktosa pada anak berusia 3 tahun sebesar 9,1\%, dan cenderung meningkat sesuai dengan bertambahnya usia, yaitu $21,7 \%$ pada usia 4 tahun, dan 28,6\% pada kelompok usia 5 tahun. ${ }^{32}$ Pada tahun 1999, Hegar dkk. melanjutkan penelitian tersebut pada kelompok umur yang lebih besar. Mereka melaporkan prevalensi malabsorpsi pada anak berumur 6-12 tahun sebesar 58\%. Hal yang menarik dari penelitian tersebut adalah tidak terlihat peningkatan kejadian intoleransi laktosa dengan bertambahnya usia anak. ${ }^{33}$

\section{Prevalensi Intoleransi Laktosa pada Anak dengan Sakit Perut Berulang}

Penelitian mengenai intoleransi laktosa sebagai salah satu penyebab sakit perut berulang pada anak telah banyak dilakukan dan didapatkan hasil yang tidak jauh berbeda. Bayless dkk tahun 1970 melaporkan 5 kasus anak usia 6-13 tahun dengan SPB yang tidak diketahui sebabnya dan hanya satu yang diduga ada hubungannya dengan faktor psikologik. Dari ke lima anak tersebut ternyata setelah dilakukan uji toleransi laktosa timbul gejala berupa nyeri perut, dan kembung, dan setelah dilakukan diet rendah laktosa terjadi perbaikan dari gejala-gejala tersebut. ${ }^{34}$

Barr dkk pada tahun 1979 juga meneliti 80 anak SPB usia 4-15 tahun dengan menggunakan uji hidrogen napas dan didapatkan $40 \%$ anak menderita intoleransi laktosa. ${ }^{35}$ Liebman pada tahun 1979 dengan menggunakan uji toleransi laktosa mendapatkan 29\% anak SPB berusia 5-14 tahun menderita intoleransi laktosa. ${ }^{36}$ Penelitian ini tidak jauh berbeda dengan penelitian yang dilakukan oleh Lebenthal (1981) yang meneliti 103 anak kulit putih berusia 6-14 tahun yang menderita keluhan SPB, dimana kejadian intoleransi laktosa didapatkan sebesar 30,4\% ${ }^{37}$. Wald, dkk (1982) dengan menggunakan uji hidrogen napas mendapatkan $30 \%$ anak SPB menderita intoleransi laktosa. ${ }^{3}$

Pendapat yang berbeda diperlihatkan oleh Christensen dkk.(1979). Mereka hanya mendapatkan 1 anak yang memenuhi kriteria diagnosis intoleransi laktosa dari 50 anak asal Denmark penderita SPB. ${ }^{38}$ Pendapat ini didukung oleh Blumental dkk (1981). Mereka mendapatkan hanya $12 \%$ anak Kauksian (Inggris Utara) dengan SPB berusia 4-14 tahun yang terbukti menderita intoleransi laktosa. ${ }^{39}$ Penelitian juga dilakukan oleh Ceriani dkk (1988) dengan menggunakan uji hidrogen napas terhadap 32 anak Italia penderita SPB dengan rerata usia 8 tahun. Penelitian ini mendapatkan kejadian intoleransi laktosa pada $75 \%$ anak. Keluhan sakit perut menghilang setelah diberikan diet bebas laktosa pada $80 \%$ anak. ${ }^{40}$

Penelitian di Hongaria terhadap 515 anak penderita SPB didapatkan hasil 48,9\% menderita intoleransi laktosa, dan hanya sekitar 18\% yang tidak diketahui penyebab SPB dan diduga faktor psikogenik. ${ }^{41}$ Peneliti lain yaitu Van der Meer dkk (1992) di Belanda menemukan kelainan organik pada $42 \%$ anak penderita SPB berusia di atas 5 tahun, dan 15\% diantaranya adalah intoleransi laktosa. Hasil penelitian ini agaknya berbeda dengan pendapat Apley yang mengatakan bahwa penyebab organik hanya sebanyak $10-15 \%{ }^{4}$

Pada tahun 1995, Webster dkk juga melakukan penelitian terhadap 137 anak penderita SPB berusia 
6-18 tahun yang terdiri dari etnis Afrika-Amerika dan Kaukasian. Setelah dilakukan uji hidrogen napas didapatkan $24 \%$ anak menderita intoleransi laktosa, $46 \%$ diantaranya berasal dari etnis Afrika-Amerika dan $20 \%$ dari etnis Kaukasian. ${ }^{10}$ Temuan ini sesuai dengan hasil penelitian sebelumnya yang menyimpulkan adanya peran faktor genetik terhadap kejadian intoleransi laktosa pada anak. Mereka menemukan kejadian intoleransi laktosa pada $65-70 \%$ anak etnis Afrika-Amerika dan Indian-Amerika, sedangkan hanya 5-15\% pada anak Amerika kulit putih, Eropa dan Skandinavia. ${ }^{20,36}$ Selanjutnya, anak yang didiagnosis intoleransi laktosa menjalani eliminasi diet yang mengandung laktosa selama 3-12 bulan, ternyata semua anak menyatakan keluhan sakit perutnya berkurang dan $74 \%$ diantaranya menunjukkan perbaikan klinis yang nyata. ${ }^{10}$

Gremse dkk (1999) mencoba menghubungkan malabsorpsi laktosa pada anak berumur 5-18 tahun yang menderita SPB dengan kejadian IBS. Dari hasil penelitian tersebut didapatkan 34\% anak menderita intoleransi laktosa dan 64\% diantaranya menderita IBS pula. Mereka menyimpulkan bahwa malabsopsi laktosa pada anak dapat merupakan faktor predisposisi terjadinya IBS di kemudian hari. Pada pasien IBS, rasa sakit perutnya berhubungan dengan gangguan defekasi dan distensi perut dan keluhan berkurang setelah defekasi. ${ }^{9}$

Penggunaan susu fermentasi (yogurt) yang berasal dari fermentasi bakteri Lactobacillus bulgarius dan Streptococcus thermophilus, yang mengandung enzim b-galaktosidase sangat bermanfaat bagi penderita intoleransi laktosa. ${ }^{16,42}$ Sedangkan penggunaan probiotik yang mengandung Lactobacillus acidophilus dan bifidobacteriae menghasilkan aktivitas laktase 4 kali lebih tinggi dibanding dengan yogurt. ${ }^{43}$

Angka kejadian intoleransi laktosa pada anak dengan sakit perut berulang di Indonesia belum pernah dilaporkan, sehingga perlu dilakukan penelitian lebih lanjut mengenai hal tersebut.

\section{Daftar Pustaka}

1. Hyam JS, Hyman PE. Recurrent abdominal pain and the biopsychosocial model of medical practice. J Pediatr 1998; 133: 473-8.

2. Firmansyah A. Aspek diagnostik sakit perut berulang. MKI 1991; 9: 525-8.
3. Wald A, Chandra R, Fisher SE, Gartner JC, Zitelli B. Lactose malabsorption in recurrent abdominal pain of childhood. J Pediatr 1982; 100: 65-8.

4. Van der Meer SB, Forget PP, Kuijten RH, Arends JW. Gastroesophageal reflux in children with recurrent abdominal pain. Acta Ped 1992; 81: 137-40.

5. Buller HA. Recurrent abdominal pain in children: Kuliah tamu bagian Ilmu Kesehatan Anak FKUI RSCM 2000.

6. Apley. The child with abdominal pain. London: Blackwell Scientific Publ, 1975. h. 3-54.

7. Hyams JS. Recurrent abdominal pain in children. Gastroenterol Nutr 1995; 7: 529-32.

8. Hyam JS, Treem WR, Justinich CJ, Davis P, Shoup M, Burke G. Characterization of symptoms in children with recurrent abdominal pain: Resemblance to irritable bowel syndrome. J Pediatr Gastroenterol and Nutr 1995; 20: 209-14.

9. Gremse DA, Nguyenduc GH, Sacks Al, Di Palma JA. Irritable bowel syndrome and lactose maldisgestion in recurrent abdominal pain in childhood. Southern Med J 1999; 92: 778-81.

10. Webster RB, DiPalma JA, Gremse DA. Lactose maldisgestion and recurrent abdominal pain in children. Dig Dis Sci 1995; 7: 1506-10.

11. Di Palma AN, Di Palma JA. Recurrent abdominal pain and lactose malabsorption in school-aged children. Gastroenterol Nutr 1997; 20: 180-3.

12. Mews CF, Sinatra FR. Abdominal pain. Dalam: Wyllie R, Hyams JS, penyunting. Pediatric Gastrointestinal Disease: Pathophysiology, Diagnosis, Management. Philadelphia: W.B. Saunders Co, 1993. h. 177-86.

13. Boediarso A. Sakit perut berulang. Dalam: Muhyi R, Abumanyu, Soefyani, penyunting. Naskah laengkap Simposium Nasional Badan Koordinasi Gastroenterologi Anak Indonesia. Banjarmasin. 2000. h. 59-70.

14. Oberlander TF, Rappaport LA. Recurrent childhood abdominal pain: Evaluation and management. International Seminars in Pediatric Gastroenterology and Nutrition, 1994; 3: 2-9.

15. Lebenthal E, Kretchmer N, Alliet P. Lactase deficiency, lactose malabsorption, and lactose intolerance. Dalam: Lebenthal E, penyuting. Texbook of gastroenterology and nutrition in infancy. Edisi ke-2. New York: Raven Press, 1989. h. 459-72.

16. Rings EHHM, Grand RJ, Buller HA. Lactose intolerance and lactase deficiency in children. Pediatr 1994; 6 : 5627.

17. Buller HA, Grand RJ. Lactose intolerance. Annu Rev Med 1990; 41: 141-48.

18. American academy of pediatrics - Committee on nutrition. The practical significance of lactose intolerance in children. Pediatr 1978; 62:240-5.

19. Garza C, Scrimshaw NS. Relationship of lactose intolerance to milk intolerance in young children. Am J Clin Nutr 1976; 29: 192-6.

20. Buller HA. Lactase phlorizin hydrolase: A review of the literature. Disertasi. University of Amsterdams, 1990. h. 2-25.

21. Firmansyah A. Laktosa dan laktase, aspek biokimiawi 
dan laboratorium. Bahan kuliah Bagian Ilmu Kesehatan Anak FKUI, Jakarta. 1999

22. Boediarso A. Perkembangan laktase dan hubungannya dengan makanan bayi. Sari Pediatri 1993; 1: 17-20.

23. Buller HA, Rings EHHM, Montgomery RK, Grand RJ. Clinical aspect of lactose intolerance in children and adults. Scand J Gastroenterol 1991; 26 , 73-80.

24. Montes RG, Perman JA. Lactose intolerance. Postgrad Med 1991; 89; 175-84.

25. Gracey M, Anderson CM. Disorders of carbohydrate digestion and absorption. Dalam: Gracey M, Burke V, penyunting. Pediatric Gastroenterology and Hepatology. Edisi ke-3. Boston: Blackwell Scientific Publication, 1993. h. 380-402.

26. Sunarto Y, Suharyono. Pemeriksaan-pemeriksaan sindrom malabsorpsi. Dalam: Suharyono, Boediarso A, Halimun EM, penyunting. Gastroenterologi anak praktis. Jakarta: BP-FKUI, 1998. h. 325-43.

27. Artan R, Biçakçi Z. Lactose malabsorption in Turkish schoolchildren. IMJ 1997; 4; 273-6.

28. Hegar B, Buller HA. Breath hydrogen test in lactose malabsorption. Paeditr Indones 1995; 35: 161-71

29. Hegar B. Uji hidrogen napas satu cara diagnostik gangguan saluran cerna. MKI 1998: 278-80.

30. Suharjono, Sunoto, Boediarso A, Sutedjo. Lactose malabsorption in healthy Indonesian children. Paediatr Indones 1971; 11: 251-4.

31. Sunoto, Suharjono, Sutedjo. Two years study on sugar intolerance in Indonesian children. Paediatr Indones 1973; 13: 241-9.

32. Hegar B, Firmansyah A, Boediarso A, Sunoto. Aktivitas enzim laktase pada murid taman kanak-kanak. MKI 1997; 2: 125-7.

33. Hegar B, Niken PY, Firmansyah A. Aktivitas enzim laktase pada murid sekolah dasar. MKI 2001;51: 154-6.

34. Bayless TM, Huang SS. Recurrent abdominal pain due to milk and lactose intolerance in school-aged children. Pediatr 1971; 47: 1029-32.

35. Barr RG, Levine MD, Watkins JB. Recurrent abdominal pain of childhood due to lactose intolerance: A prospective study. N Engl J Med 1979; 300: 1449-52.

36. Liebman WM. Recurrent abdominal pain in children: Lactose and sucrose intolerance, a prospective study. Pediatr 1979; 64: 43-5.

37. Lebenthal E, Rossi TM, Nord KS, Nord KS, Branski D. Recurrent abdominal pain and lactose absorption in children. Pediatr 1981; 67: 828-32.

38. Christensen MF. Prevalence of lactose intolerance in children with recurrent abdominal pain. Pediatr 1980; $65: 681$.

39. Blumenthal I, Kelleher J, Littlewood JM. Recurrent abdominal pain and lactose intolerance in childhood. Br Med J 1981; 282: 2013-4

40. Ceriani R, Zuccato E, Fontana M, Zuin G, Ferrari L, Principi N, dkk. Lactose malabsorption and recurrent abdominal pain in Italian children. J Pediatr Gastroenterol Nutr 1988; 7: 852-7.

41. Hovarth K, Horn G, Hassan BG, Szamosi T, Nemes NA, Bodanszky H. Chronic recurrent abdominal pain and lactose malabsorption in childhood. Orv Hetil 1990; 131: 2631-5 (abstrak).

42. Donan CG, Chabanet C, Pedone Ch. Milk-fermented with yogurt cultures and Lactobacillus casei compared with yogurt and gelled milk: influence on intestinal microflora in healthy infants. Am J Clin Nutr 1998; 67: 111-7.

43. Vessa TH, Marteau Ph, Zidi S, Rambaud JC. Digestion and tolerance of lactose from yogurt and different semisolid fermented dairy products containing Lactobacillus acidophilus and bifidobacteria in lactose maldigester- Is bacterial lactase important? Eur J Clin Nutr 1996; 50: 730-3 